\title{
SECONDARY RESPONSES TO FEAR AND GRIEF \\ IN GREGORY OF TOURS' LIBRI HISTORIARUM*
}

\author{
Ron F. Newbold
}

\begin{abstract}
Bodies of evidence drawn from the occurrence of Latin words for fear and grief in Gregory's history form the basis for this study. Although the causes of these emotions and their distribution across social status are noted, discussion centres on the secondary, more cognitive and considered manifestations of fear and grief, rather than, for example, initial trembling and wailing. Secondary responses to fear may display avoidance and flight from the threat, attempts to placate and conciliate, taking extra precautions, and counter-phobically using aggression to overcome fear and turn the tables on the threat. Secondary responses to grief and sorrow may manifest in funeral rites, consolation, violence against others and the self. Grief at the sorrow and suffering of others can lead to intervention, petition and prayer. Prostration and tears typically reinforce supplication and petition. Grief at one's own sins evokes displays of penance and pious works, as well as prayer and prostration. Gregory commends placatory and penitential responses to fear and grief. These tend to be more successful. They are also one of the chief marks of pious, Christian humility.
\end{abstract}

\section{Introduction}

This is not a study of fear and grief in Merovingian Gaul but of how they are presented in Gregory's History. Although notice is taken of general or hypothetical statements about fear and grief, it is the actual reported occurrences of these emotions, indicated by the presence in the Latin text of key emotion words, which make up the body of evidence and are the focus of attention. The occurrences of these keywords provide sufficiently large thought-samples-for-study from Gregory's material. ${ }^{1}$ The experience of these emotions in Gregory's individual or group characters obviously extends much further than what the keywords flag. However, by limiting the body of evidence to emotions flagged in this way, potentially unsound inferences and attributions are avoided. ${ }^{2}$ Generally, emotional responses can be instinctive and immediate, or they can be cognitive, based on a judgment and an appraisal of the stimulus and whether or not affect should be displayed and, if so, how. Although mention of the causes and the immediate, primary responses to fear and grief cannot be completely omitted from this study of their place in Gregory's major literary creation, it is the secondary, less instinctive and more cognitive responses that offer most scope for delineating their role in Gregory's thought-world. This delineation is the objective of the study.

\footnotetext{
* My thanks to the SHT referees for suggestions to improve this paper.

${ }^{1}$ Creating a body of evidence for study in this way accords with standard content analysis procedures. See Krippendorf 2004; Smith 1992.

${ }^{2}$ References were gathered by means of a concordance, St-Michel 1979.
} 


\section{The nature and alleviation of fear}

Emotions are not unitary phenomena but complex bundles of reactions. It is possible to feel fear, grief, shame and anger, or various other combinations, simultaneously. Emotions are both universal bodily feelings and cultural constructions, both innate, biological responses and social prescriptions. As a biological phenomenon, fear, for example, registers in a standard physiological pattern across time and culture but the causes, manifestations, interpretations and evaluations of it can vary, not only across cultures, but also within cultures. ${ }^{3}$ Fear is a social construction to the extent that it is focused on and activated by certain things, such as God, plague, pollution, tyranny, but not on others. In general, however, fear, whether fear of suffering something or fear to do something, excites the instinct for survival, for extrication from dangerous situations. As an anticipation of suffering something unwelcome, it is the fear of the unknown or uncertain, diminishing whatever sense of security, control and comfort one had been enjoying. In its most threatening forms, such as being helpless in the hands of torturers, or when facing death, the fear of the unknown presses in particularly strongly, but the loss, or prospect of losing, habitat, wealth, position, income, and the relationships and social support of friends and kin, can also present an abyss of uncertainty, an agony of exposure to a new, uncontrollable, unpredictable environment. ${ }^{4}$ It can be strongly felt on behalf of others. Fear of injury or appearing weak often fuels a drive to make oneself powerful, and therefore fearsome to others, or to seek greater control over one's environment, to do something that might attract the interest of a historian. One traditional antidote to all types of fear is religious faith, the faith that some divine being will shield one from the worst life has to offer, will bring aid, or will bestow the comfort that, viewed in the light of eternity, one's pain and suffering are transient and comparatively trivial, or that it has some ultimately beneficial and just purpose. To the religiously faithful, therefore, manifestations of fear can, amongst other things, be marks of insufficient faith in God's wise and protective presence. Moreover, the pious and innocent should not have anything to fear on Judgement Day. In practice, few people are so god-centred or god-infused that a sudden and serious threat does not trigger the instinct for survival that is fear. Nevertheless, piety and faith in an interventionist God or saint should reduce fear. Gregory was very much of a society that relied on a sense of guilt and fear of divine wrath and retribution to curb criminal and anti-social behaviour. ${ }^{5} \mathrm{~A}$ prime catalyst of fear is the perception of superior strength outside oneself. Although Gregory's phrases, timor and metus Dei, at times seem mean respect rather than fear, he is quite sure that recognising God's fearsome power and dreading an eternity of torment in hell are

\footnotetext{
${ }^{3}$ The bibliography on this issue is vast. For a recent survey of both these approaches to emotion, see Milton and Svasch 2005 and, apropos of Gregory, Rosenwein 2002a. Rosenwein 2006: 55-56, dismisses the idea of emotional childishness and impulsiveness being the medieval norm, and stresses the basic continuity of ancient, mediaeval and modern thought about emotions: "There is, then, no reason to worry that studying the emotions of the Western Middle Ages is any more anachronistic than studying its universities, ideas, or political institutions". Cf. 202. On emotions as multiple phenomena, see, for example, Averill 1994: 99-102; Konstan 2006.

${ }^{4}$ For the role of fear, and some manifestations of it in Gregory's world, see DeNie 1987: 32, 36, 48, 88, 101, 108, 232, 279 As an apprehension to do something and thereby risk incurring some of these losses, fear is largely captured by our word "timidity". See Davies 1987 on the various types of fear.

${ }^{5}$ See DeNie 1987: 88, 101, 108.
} 
highly desirable attitudes, and that not to fear God or post-mortem retribution exposes both an individual and an community to all manner of ills. In this respect, Gregory's world-view has clear pagan antecedents.

\section{Who fears and what is feared}

The 16 Latin keywords used are as follows (the number of occurrences is given in brackets): terror (7), territus (13), conterritus (5), exterritus (5), metus (12), metuere (43), trepidus (2), pertimescere (1), timere (46), timor (29), timidus (2), formido (2), formidare (4), fumidare (1), pavor (9), paviscere (2). These occurrences (totalling 183) yield 105 different episodes where a reason for fear is given. The smaller figure comes about because description of an episode of fear can contain more than one fear word, that is, the same word is repeated or synonyms are used Or else, no reason for fear is given, or there is a simply a wish that someone fear something. ${ }^{6}$

If we distribute over the status of the fearers the 105 instances of people fearing for some clear reason, we have a distribution that embraces all levels of society:

Royalty: $\quad 28$ (includes kings, queens, princes/esses, Roman emperors)

Magnates: 21 (includes nobles, high officials, envoys, generals, courtiers and their family members)

Clergy and religious: 20 (includes monks, nuns, hermits)

Lower orders, populations in general: 36 (includes soldiers, ordinary citizens, servants, "many", “all”)

Despite their greater power and resources, members of royal families are reported as fearful most often, partly because they are a focus of Gregory's attention and partly because in some ways they have more to lose and worry about. ${ }^{7}$ Of the individual fearers, 9 are women. Causes of fear can be grouped into categories as follows:

1. Fear of loss of dear one or property or membership of a body: 11.

This includes a community fearing the loss the of a beloved bishop, individuals losing a son/grandson or husband, being parted forever from relatives, an army losing its commander, not inheriting an expected estate, excommunication from the church. ${ }^{8}$

\footnotetext{
${ }^{6}$ For this reason 42 instances are not discussed in the analysis below. Some examples: Gregory wishes other peoples might also fear God's power, 5. pref.; he expects a wicked priest to fear judgment day, 10.13; Guntram denies he is fearful, 8.4; an abbot fails to instil enough fear into his monks, 4.33; Chilperic's army shows no fear of God and St. Martin, 5.14; nor do Fredegund and the people of Sodom fear God, 7.15, 6.5, a common complaint or problem in Gregory; Hermangild hoped his father, King Leuvigild would be alarmed by an attack from his (Hermangild's) troops, 6.43; Frankish troops pretended they were afraid, 2.9.

${ }^{7}$ Magnates did too, since their power depended so much on their wealth. See James 1982: 131. On the insecurity of royal lives, see, for example, Wood 1994: 89, 99, 122.

$82.5,2.7,2.23,3.18,5.22,6.18,6.45,8.30,9.33$.
} 
2. Fear of death, (further) assault, punishment, harsh criticism, injury from humans to one's person or property: 53. (Both 1. and 2. can involve loss of status or reputation, in 1 . because a prestigious relationship is no more.).

This includes fear of invasion or attack by foreign and local armies and troops, of assault by angry tax payers, subjects, master, personal enemies, rebels/plotters/traitors, bandits and thugs; of punishment for a crime or failure/disobedience, even if only by association; of revenge for a harm done to another. ${ }^{9}$ The emphasis in this category is on physical violence, but not exclusively, for it includes bishops fearing abuse and criticism from a king (5.18) and Queen Fredegund fearing the damage to her reputation if the murdered Prince Chlodovech's corpse should be found and honourably buried (8.10).

3. Fear of the supernatural or uncanny or highly unusual, of divine disapproval and punishment, or of simply the power of divine proximity: 35 .

This includes events such as wild animals entering a city, portents in and fire from heaven, earthquake and flood, witchcraft, a disturbing dream, plague, Jesus' disappearance from the tomb. ${ }^{10}$ It is this cause which makes fear most like a social construction.

4. Fear for others that may elicit an intervention on their behalf, or attempt to assist: 6 .

Thus Gregory fears for some church robbers and for Count Leudast facing execution and further deaths from a feud. Kings fear for their children and their subjects. ${ }^{11}$

Clearly, these causal categories can overlap to some extent and fearfulness about one threat can increase in intensity and range when prevention fails, the dreaded state actually occurs and threats multiply. Fear almost always stimulates some form of prevention or escape. Otherwise, the worst may befall. Sometimes no action is possible and one can only rely on the great neutraliser of fear, hope. On 27 occasions there was no reported response by Gregory. We are left with a collection of 78 instances. Of these, 53 instances (67\%) narrate successful or apparently successful (Gregory reports no adverse outcome) measures to reduce or eliminate the threat, the source of fear, at least temporarily. At times, there was reason for cheer in Gregory's often harsh world. Clearly unsuccessful measures total 19 (24\%), while there are 3 references for which the test is not applicable and 3 case where the response is a bit of both (see below).

Gregory does not dwell on or give much detail about the primary, physiological responses of fearers. ${ }^{12}$ His reports of secondary responses to the four causal categories, above, themselves fall into four broad categories, all of which seek to re-

\footnotetext{
${ }^{9} 2.8,2.9,2.20,2.34,3.36,4.13,4.18,4.46,5.18,8.43,9.41,10.18$.

${ }^{10} 2.34,3.28,5.17,6.41,7.22,10.1,10.18,10.31$.

${ }^{11} 6.10,6.32,6.45,7.47,9.21$.

${ }^{12}$ We rarely find the immediate physiological manifestations or primary responses of fear such as pallor, perspiration, trembling (mentioned once), loss of speech, wide eyes, do not figure much in a historian who is often vivid and dramatic but rarely visually detailed, unlike the authors of the Old Testament who relished mention of visceral detail. See Kruger 2004: 213-25.
} 
duce the pain, uncertainty and helplessness that anticipation of (further) loss or harm tends to induce:

\section{Fleeing, staying away from, changing direction to avoid a threat, seeking sanctuary.}

Obviously, these responses relate most to threats of violence or severe impairment, such as a living death in exile and they include 5 instances of committing suicide to prevent an even worse fate. ${ }^{13}$ Of 32 instances of this fugitive or avoidant response, 20 are successful, 11 unsuccessful and 1 a bit of both. ${ }^{14}$ Staying away from danger is illustrated by the would-be plunderers who approached a monastery that contained St. Martin relics. Warned by the monks, some were sufficiently moved by fear of God to retire across the nearby river. Nineteen others, who attacked the monks and looted the monastery, perished in the river (4.48). In 589 there was a serious disturbance at a convent in Poitiers when some nuns sought to displace the abbess. Bishops and other clerics tried to settle the revolt by excommunicating the recalcitrant nuns but were set upon by thugs. They fled after being savagely beaten and bloodied, and thereby avoided further harm. ${ }^{15}$ When King Childebert II sent troops against Dukes Berthefred and Ursio and had them killed, "many", presumably those connected with the slain men in some way, had reason to think they could the suffer the same fate. Therefore, in their fear of the king, (pertimiscentes regem), they fled into other regions and thus avoided a similar fate. ${ }^{16}$ Magnates and rulers had much to fear from each other. Being driven to remove themselves from proximate danger was more difficult in one way for magnates because they had more to leave behind and lose. However, they had more resources with which to survive in a different location. A case in point is that of Duke Desiderius who in 587 fled with all his portable possessions into the territory of Toulouse, "fearing (timens) lest vengeance be exacted from him by Childebert II because of a longstanding enmity" (8.45). Desiderius then raised an army with which he attacked the Goths but was killed in the battle. Likewise only temporarily successful was the rather different flight of Bishop Cautinus, fleeing from city to city to stay ahead of a plague that afflicted Gaul in 571. He was infected and died when he eventually returned to his home in Clermont (4.31). Cautinus' dereliction of duty and lack of faith in God's protection contrasted sharply with the priest Cato who stayed at his post in Clermont and ministered to the needy before he too succumbed. Flight from a church struck by an earthquake during Mass brought only temporary respite for the congregation, for they were then afflicted by a great plague. ${ }^{17}$

${ }^{13}$ Count Palladius facing execution by King Sigibert, 4.39; imprisoned would-be assassins of King Childebert facing torture, 10.18; King Theudebert's associate, Secundinus, facing the prospect of falling into the hands of a bitter enemy, 3.33; similarly, Prince Merovech, 5.18; and the serfs of Chilperic who feared (metuebant) virtual exile in Spain away from their dear ones, 6.45. These responses are classed as unsuccessful.

${ }^{14}$ Viz. 10.9, when the remnants of Duke Ebracher's army, sent by Guntram, returned from a campaign against the Bretons. They feared returning through territory they had pillaged on their way out and took an alternative route to avoid the vengeance of the inhabitants, but some of them (manus parva) were nevertheless caught, stripped, beaten and subjected to every indignity.

15 9.41. For two other examples of episcopal flights from fearful imprisonment and imminent violence, see $6.31,6.36$.

16 9.12. Cf. 7.33. For other successful flights, by individuals and groups, see 4.16, 4.44, 6.12, 9.38.

17 5.17. There were mass flights from widespread earthquakes in 580, 5.33. 
Unsuccessful flights or avoidances include the pretender Merovech hiding from Chilperic near Reims and fearing the vengeance of his enemies, not least of whom was Fredegund, ordered his servant to kill him (5.18). In view of the atrocities subsequently inflicted upon the servant and other allies, Merovech's choice of exit was wise. Given the violent tenor of life, summary punishments, endemic treachery and disorder, and weak legal safeguards for the protection of life and limb, religious sanctuaries played an important role in Merovingian society for providing at least temporary safety. Just as pagan temples once offered asylum to those in danger, ecclesiastical structures provided a sacred refuge for fugitives. They were also a constant source of conflict with civil law and secular authority. Seeking sanctuary in a church might offer a temporary respite from danger but only if besiegers were prepared to respect the building. Guntram's agent, Claudius, seeking sanctuary in an abbot's cell after murdering Chilperic's former official, Eberulf, who had in turn sought sanctuary in St. Martin's church from Chilperic's wrath, was himself, together with some followers, murdered on holy ground. Eberulf was in Gregory's eyes a thoroughly despicable character but even he merited God's intervention (Dei ultio) when these oases of security were violated. ${ }^{18}$ The ability to instil fear in another establishes superior status and power. By avowing the at least temporary superiority of the feared one, flight can be a form of flattery. However, flight, at least initially, shows little or no confidence in the humanity or mercifulness of the source of the threat, and often with good reason.

2. Submissive, compliant, placating behaviour, designed to reduce or eliminate the threat by even more explicitly acknowledging the superiority of the more powerful or dangerous.

This response includes keeping quiet in the face of bad behaviour by the powerful, prayer on behalf of oneself or of others, seeking pardon, performing various forms of penance, and can range from making a treaty with the source of fear to undoing one's offence, such as returning stolen goods. It includes intercessionary petitions by a third party. ${ }^{19}$ Of 28 instances of this appeasing response, 27 appear apparently successful, at least temporarily, 1 clearly unsuccessful. The one unsuccessful case involves the arrested would-be assassin of Childebert II proclaiming his prior abandonment of the murder plot and revealing details and accomplices. He was nevertheless tortured to extract further details, which he supplied (10.18).

In contrast to this instance, a cleric hired to kill Bishop Aetherius, a man of saintly compassion and mercifulness, was so fearful (timore perterritus) that he was unable to complete the task, fell at the bishop's feet, revealed his employers, begged for forgiveness and was let go (6.36). In 584, King Leuvigild of Spain, fearful of an attack from Childebert to avenge the wrongs done to his sister, who was also Leuvigild's daughter-in-law, Ingund, sent an envoy bearing many gifts to Chilperic, presumably to prevent him joining his brother in such a venture, perhaps hoping Chil-

\footnotetext{
${ }_{18}$ Claudius was slain by Eberulf's vengeful followers, 7.29. In the cases of Berthefred and Ursio sanctuary also failed, 9.12. Duke Austrapius was more fortunate when he sought sanctuary in a church of St. Martin from the vengeance of Prince Chramn, 4.18. For Merovingian asylum, see Frye 2003. For a study of 261 instances of civilian interpersonal violence in books 2-10 of the History, see Newbold 1994. ${ }^{19}$ Into category 1 go instances of flight not followed by any overtly placatory behaviour. Into category 2 go instances of overtly placatory behaviour, even if preceded by flight, e.g., 4.46, Ursus seeking the sanctuary of a church after his slaves had murdered a rival and then sending gifts to King Sigibert.
} 
peric might exercise some restraining influence on Childebert. ${ }^{20}$ Other successful cases include Bishop Palladius who, accused of treason and threatened with banishment by Guntram's agent, Duke Antestius, being able to avoid that fate by transferring possession of a house he owned to Antestius (8.43); the Visigothic King Alaric II acceding to Clovis' demand, backed by the threat of attack, to surrender the defeated and fugitive King Syagrius (2.27); the defeated King Gundobad agreeing to become Clovis' vassal. ${ }^{21}$ These are explicit gestures of inferiority and weakness that were sufficient for their adversaries. A somewhat different form of submission was the conduct of the anxious and sad wife of Rome's generalissimo, Aetius, who in 451 was "in great danger and locked in a difficult struggle with the enemy", Attila the Hun. She prayed (praecabatur) unceasingly in churches for her husband's safe return and thus eased some of her helplessness by doing something constructive. This petition on behalf of another by a fearful and God-fearing woman had a good outcome.22

Gregory is pleased to record the power of dead saints and martyrs to enforce good behaviour, especially upon the powerful who might otherwise be hard to control because they lacked sufficient deference and humility. In 534, a Gallic army besieging Saragossa withdrew out of respect (timentes) for the faith and piety of the besieged and without suffering adverse consequences. It was the besieged's carrying of the tunic of the blessed martyr Vincent round the city wall that particularly shook the besiegers (3.29). The humility of the besieged in turning to God in displays of penitence and piety (fasting, hairshirts, singing psalms) as well as the mural circumambulation first reduced, and them banished, the fear they must have felt. Here it was not a case of the aggressors requiring a gesture of obeisance as of they making one to the power of St. Vincent. When in 544 King Chlothar proposed to make the churches divert one third of their revenues to his coffers, Bishop Injuriosus of Tours so furiously denounced the measure that Chlothar, "fearing the power of the blessed Martin", fell over himself in his apparently successful desire to placate the bishop: he sent him gifts, begged his forgiveness, condemned what he had done and asked Injuriosus to pray to Martin to help him..$^{23}$ Examples such as that of Injuriosus needed to be drawn upon in standing up for what was right and just. Otherwise, submissive behaviour and failure to speak up was a cowardly dereliction of duty, as Gregory reminded his fellow bishops at the trial of Bishop Praetextatus before Chilperic. They kept quiet in fear of incurring the king's wrath. Gregory, however, spoke up (5.18).

We have seen earlier the fate of a congregation who fled as an earthquake shook their church during Mass: immediate safety in flight but subsequent affliction with plague. A display of submission to God was a better option. When the people of Vienne were terrified (pavore perterriti) by a series of uncanny and disturbing phenomena, including earthquakes, Bishop Mamertus employed obsecration to God and enjoined piety and penance upon the people of Vienne as a way of freeing them from

\footnotetext{
${ }^{20} 6.40$. For further instances of seeking to placate by sending envoys and gifts and seeking treaties, see $4.42,4.49,6.18,6.42,9.18$.

${ }^{21}$ 2.32. Earlier, Gundobad had been intimidated by Clovis into handing over his daughter Chlotild to be Clovis' wife, 2.28.

22 2.9. For another example of fear on behalf of others leading to petitionary and constructive behaviour, Gregory on behalf of some thieves, see 6.10. They were spared by Chilperic.

${ }^{23}$ 4.2. 9.30 may be also be referring to this episode, or to a similar one involving Chlothar.
} 
these terrors, which could easily be taken as signs of divine anger. ${ }^{24}$ "Thereupon the terrors ceased. The fame of this deed went through all the provinces and moved all priests to behave likewise (then and since then)...in a spirit of contrition". Penitential rituals are a potent means of reducing and controlling fear, and manifestations of the supernatural and uncanny in particular evoke ritual responses. ${ }^{25}$ Fear that turns people to deeds of virtue via prayer and penance is to be welcomed. The armies of Childebert I and Theudebert, drawn up against their brother Chlothar were terrified by thunder, lightning and hail, while nothing disturbed the peace around Chlotar's army. Childebert and Theudebert did penance, sought God's pardon for their nonfraternal behaviour, and sent envoys seeking peace. Gregory has no doubt that this was due to the night-long prayers of their mother, Queen Chlotild at St. Martin's tomb: "No-one should doubt that this came about through the prayers of the queen and the power of St. Martin" (3.28). In the case of Berthegund, who deserted her husband for a convent, the threat of excommunication by bishops and therefore hellish torment in the next life that made her come to heel and return to him (9.33). While usually very supportive of anyone embracing the religious life, compliance to episcopal authority could matter even more to Gregory. A different kind of fear, fear of punishment by humans in this life made Guntram Boso's servants meekly return the jewels they had stolen from a tomb in a church shortly after they had begun their flight (8.21).

3. Taking extra precautions, such as increasing one's bodyguard, removing or sending someone away or providing an escort, to prevent fears being realised, can also be warning signals to a potential threat.

Of 13 instances, 4 appear successful, 6 unsuccessful, 2 a bit of both and 1 is unanswerable. These include actions like the Roman emperor Valentinian III killing his generalissimo, Aetius, who he feared might overthrow him (2.8, successful), Godegisel, the Burgundian ruler who drove his people from besieged Vienne when he was besieged and threatened by famine by his brother Gundobad c. $500 .{ }^{26}$ This precaution availed him not because amongst those who were expelled was a man who knew how to gain entry to the city. Gundobad was informed, the city was taken and although Godegisel took refuge in a church, he was justly slain because it was a church of the heretic Arians. Chilperic provided a large armed escort for his daughter Rigunth, setting forth for Spain to be married to the son of Leuvigild's son with much treasure. The treasure was eventually stolen at Toulouse, in part because so many of Rigunth's escort had deserted her, so the precaution was ultimately unsuccessful (6.45). Fredegund's fear (metuens) and subsequent attempt to prevent the body of Chilperic's son, Chlodovech, whose destruction she had encompassed (see

\footnotetext{
${ }^{24}$ 2.34. Cf. the similar injunctions of Guntram to deal with a plague at Marseilles, 9.21.

${ }^{25}$ See Chodorow 1991: 89-91, who comes close to suggesting the primary purpose of ritual behaviour is to tame fear and banish the abyss of uncertainty.

${ }^{26}$ 2.33. Cf. 5.22, Fredegund rejecting her son Samson in fear of his early death. She was ill herself at the time which might help explain her state of mind. The boy died before turning five. It is hard to classify this as successful or unsuccessful. It might be that Gregory, in his antipathy to the queen, has distorted a measure to prevent the child being infected with his mother's illness, but he tells us that she was rebuked (obiurgata) for this by Chilperic. Chilperic was being more constructive when he sent his son, the future Chlotar II, away to protect him from witchcraft, 6.41 .
} 
below) being found and given a honourable burial failed. ${ }^{27}$ Gregory twice mentions a fearful Guntram on his visit to Paris in 584, going everywhere with a large armed escort. ${ }^{28}$ The second reference tells of Guntram hearing of a plot to murder him and strengthening his bodyguard. It is possible that this was the news that made him so distrustful in the first place. Grippo and two companions, Childebert II's envoys to the emperor Maurice, found themselves besieged in a house in Carthage and took the precaution of extracting from the besiegers a guarantee of immunity from harm. Unfortunately, when they emerged, Grippo's companions were killed but Grippo managed to save himself by putting the fear of God, of Childebert and of Maurice into the assailants, now killers of innocent royal envoys (10.2). So the precaution was only partially successful and Grippo's response was counterphobic. While that helped save him, a reminder of the consequences of violated oaths, though not mentioned by Gregory, is likely to have been a further factor in determining the situation. The most disinterested fearful response is perhaps that of Gregory himself. Fearful (timui) that his enemy Leudast might be killed by Fredegund, he "summoned his father-in law, apprised him of the danger and urged him to warn Leudast to be on his guard while her anger was still hot": let him delay seeking a pardon from Chilperic. Gregory's precaution failed. Leudast disregarded the warning and immediately sought a pardon from Chilperic. Fredegund had him slain. ${ }^{29}$

4. The final category of response is the counter-phobic, angry, sometimes violent, and on one occasion miraculously calm, behaviour, that reduces or eliminates the threat, or turns the tables in a form of revenge, and seeks to make the threatener afraid.

A good example of the last is abbot and hermit Maxentius, who calmly went forth to meet soldiers who were threatening the monastery and terrifying the monks. He was not only completely calm (intrepidus) but when one of the soldiers raised his arm to strike Maxentius with his sword, the arm petrified and the sword fell to the ground. It was now the soldiers who were afflicted with great fear (timore maximo). They rejoined their army fearing (timentes) lest they suffer a like fate (2.37). Also placed in this category is the far less happy reaction of Queen Chlotild when confronted with the choice of having her grandsons killed, or shorn and therefore ineligible to become rulers. The messenger who delivered this ultimatum came from her sons Childebert I and Chlothar. Angry and distraught, as well as frightened, she may have tried to turn the tables by saying she would prefer them dead rather than shorn. If she thought she was calling their bluff, she failed, for the boys were then murdered (3.18). The frequent concomitant of fear, a feeling of helplessness, is often mitigated if it is largely replaced by anger or aggressive behaviour. Appropriately, Fredegund supplies one of the most graphic examples of a counterphobic response to fear. In 580, terrified (perterrita timore) by the boasts of her stepson Chlodovech of what he would do when he became king and both alarmed and furious when told by another that he, his mistress and her mother were responsible for the recent death of her sons,

\footnotetext{
27 8.10. Gregory blames Fredegund for his death. Perhaps the most vile and therefore deservedly unsuccessful precaution was that of Queen Deuteria, fearing the designs of her husband Theudebert upon her daughter. She had the daughter killed but Theudebert divorced her anyway, 3.26-27.

${ }^{28}$ non fidus, 7.8, metuens, 7.18. On fear as the main driver of Guntram's conduct, see Dalton 1927: 1.51.

${ }^{29}$ Unsuccessful because Leudast, rejecting the advice of his enemy and would-be helper, immediately sought a royal audience, and was slain, 6.32 .
} 
Fredegund had the mistress beaten, shorn and tied to a stake, the mother tortured and burnt alive, and Chilperic turned against his son by what she told him and by her demand for vengeance. She had the prince, who protested his innocence, arrested and murdered, his ex-queen mother cruelly killed, and his sister immured. And there were other victims of this furious response (5.39). Of 3 instances in this category, 1 appears unsuccessful, 2, so starkly contrasted (Maxentius versus Fredegund), successful.

5. There are 2 instances where the only mentioned response of the fearful person talking to someone about their fear, ${ }^{30}$ plus the above-mentioned case of Fredegund (n. 26), where a successful/unsuccessful test is not applicable.

\section{The nature and alleviation of grief}

If average life expectancy at birth in Gregory's violent and insecure world was comparable to that of the Roman Empire, about 25 years, bereavement and constant reminders of life's uncertainties gave people plenty to fear and grieve. Besides, losses of various kinds (health, strength, property, wealth, relationships, roles, habitat) and the grief and change they cause are part of everyone's life. ${ }^{31}$ Like fear, grief offers opportunities to manifest one's faith in and closeness to God, his ineffable majesty and mercy. Such faith can prevent undue attachment to worldly things and their loss. Some of the losses that people grieve over, such as loss of wealth or the privileges of power, may not seem particularly laudable to Gregory, in that they can appear as egocentric sulking and a mark of lost faith in God's wisdom, righteousness and compassion. However, grief at sinful lapses of virtue and piety, on the part of oneself or of others, tears shed for the sorrow of the world or to enhance the power of prayer, and penitential weeping and lamentation are extremely laudable. Such grief was, for Gregory, a touchstone for faith and path to divine truth. ${ }^{32}$ It is culturally distinctive. When felt at the pain or suffering of others, is a mark of sainthood. It is also a nonverbal gesture in the direction of heaven where angels and even God may weep. Hence, occasions for lamentation and tears of sorrow can be valued gifts if they transform and comfort, if they impel penance and piety, if they mirror the celestial. Grief has a number of aspects, including society-mandated forms of expressing private wounds that either cloak or exaggerate the exact degree of the pain felt. ${ }^{33}$ As bishop, Gregory would constantly have to supply comfort and explanation for the bereavements and other misfortunes that repeatedly darkened the lives and moods of his flock. Citing God's displeasure at spiritual deficiency, a displeasure that might

\footnotetext{
30 The unnamed count who was responsible for the custody of Bishop Theodore when Theodore escaped, 6.24, and Gregory relating a frightening dream about his enemy Eberulf to Eberulf himself, 7.22 .

31 See Goldsworthy 2005: 167-78, on how common some form of loss is in people's lives. On the demographic factors that would have been present in Gregory's Gaul, see Smith 2005: 51-80, a chapter entitled Living and Dying.

32 See Kristeva 1989: 8, on the "sinfulness" in the Christian tradition of some forms of sorrow.

33 Expressions of grief are particularly culture-variable. See, for example, Rosenblatt et al. 1976; Harre 1986; Klass et al. 1996.
} 
manifest as a plague or earthquake, was a convenient recourse. Gregory is comfortable with people incurring grief when they do things like violating the sanctity of churches and holy places, especially when that violation elicits a miracle or supernatural sign, reminders of superior power that should be feared.

Thus, like fear, grief may be a consequence of behaviour that fails to please God, saints or martyrs, who act as both chastisers and comforters. Both fear and grief can lead to feelings of anger - or despair, even suicide, but that is the Devil's work (4. 39). The two emotions can co-exist and reinforce each other. Grief may spark anxiety attacks. In turn, grief caused by some loss can awaken fear of facing the future without someone or something that has in the past provided security, comfort, reputation or status. In at least 6 episodes in Gregory's history, terms for fear and grief occur together. ${ }^{34}$

\section{Who grieves and what is grieved}

As with fear, to focus on manifest rather than latent, symbolic or disguised content, this study of grief is limited to a list of indicative keywords. These words are in two groups. The first group consists of synonyms for grief and grieving, as follows (the number of occurrences is given in brackets): meror (1), maestus (2), mestus (2), luctus (6), contristatus (7), orbatus (3), tristitia (2), tristis (2), tristicus, (1), dolere (5), dolor (19, omitting a further 15 instances when dolor appears to refer to purely physical pain), condolere (8), desolatio (1). The second group, also of 13 different words, consists of primary responses which are indicators of grief and grieving, such as weeping, groaning, wailing: gemitus (7), ingemiscere (5), lacrimae (25, discounting 4 occasions of clearly joyful tears), lamenta (3), lamentare (6), lamentatio (1), lamentabilis (1), flebilis (1), flere (19), fletus (17), planctus (5), plangere (6), (h)eiulare (3). A total of 158 occurrences, but some of them cluster in or are repeated in a particular episode of grief (e.g. 1.47) or else occur in connection with failure to grieve or admonishment not to grieve, such as the injunction by a bishop to his flock not to mourn his imminent death (2.3; cf. 10.13), Fredegund's failure to mourn Chlodovech's death, 5.39, and Chilperic's failure to grieve for his sins. ${ }^{35}$ These words capture enough instances of grief in Gregory to give a reasonable body of evidence to work with. If we distribute instances of grief in the collection over the status of the grievers, we have 94 instances, distributed as follows:

Royalty: 32 (Kings 15, queens 11, princes/esses 6)

Magnates: 7

Clergy: 30 (Bishops, including Gregory 22, priests, deacons 3, monks, nuns, abbots, hermits 5)

Lower orders, population in general: $\quad 26^{36}$

\footnotetext{
${ }^{34} 2.7,2.23,2.30,3.18,4.13,9.30$.

35 10.49. More laudable was Queen Chlotild's refusal to mourn the death of her baptized infant son on the grounds that he would be in heaven, 2.29 .

36 Some of these instances, where they include a whole population, obviously could include those of higher or clerical status. At 6.35, the grief of a queen and courtiers at the death of a prince are specifically
} 
God also grieves (condoluit) once, giving a total of 96 . Of the individual grievers, 13 are women.

If we distribute instances of grieving according to cause, we have the following categories:

1. Bereavement, loss of dear one:

2. Loss of status, possessions, habitat; imminent loss of own life:

3. Grief on behalf of the (potential) suffering or misfortune of others:

4. Grief caused by one's own sins and failures:

17

5. Distaste for doing something unpleasant:

\section{Secondary responses to grief}

\section{Responses to bereavement.}

Mostly, the responses to grief mentioned by Gregory are of the typical primary ones of tears, sighs, groans, wailing and lamentation..$^{38}$ Secondary responses to grief in Gregory tend to cluster around protection, prayer, petition, penance, prostration and (demonstrations of) piety. Most responses noted by Gregory have one or more of these elements. They are often accompanied by tears, so that primary and secondary responses appear to fuse. As we shall see, below, the nature and feeling behind tears can shift. The tearful and supplicatory behaviour manifested in the examples below is to a considerable extent a ritualised expression of grief and entreaty but is encouraged by the cultural belief that tears enhance the power of prayer, that weeping is a pious imitation of the tears of saints, angels, Jesus, God, that tears are a cherished offering to God and a way of getting closer to Him, that the sins and sorrows of the self and the world demand not only tears, per se, but tears in combination with prayer and supplication. Also, the distress, the sheer stress and fear (and sometimes anger) of real or prospective loss that impels prayer, can also spontaneously induce tears. As with fear, there are some cruel and excessive responses to grief, including suicide, such as Queen Austrechild, about to die, ordering, and securing, the deaths of her unavailing doctors (5.25). There are also some responses that are special to grief, such as memory-erasure and consolation, and the both heartfelt and ritual marks of respect, consolation and farewell that take place at funerals. These responses are, naturally, commonest in the case of bereavement. Burials are occasionally mentioned in Gregory, such as that for Guntram's nephews, Chlodovech and Merovech. Gregory mentions these because they marked the thwarting of their stepmother Fredegund's efforts to deny them honourable burial (8.10). In the case of Duke Rathar burying his son, this detail is mentioned by Gregory to emphasise the pain of one, a magnate,

mentioned, and on other occasions we could reasonably infer (but have not here) that royal grief was felt further down.

${ }^{37}$ This figure does not include the tears of Bishop Aravitius and the hermit Hospicius, 2.5, 6.6, at their imminent deaths are more akin to spiritual weeping and may have a component of joy at the prospect of entering paradise. See below.

${ }^{38}$ At 4.39, a mother faints at seeing her son's body, dead by his own hand. Fredegund beats her breast with her fists, 5.34 . 
who was an enemy and plunderer of the church, and who therefore incurred God's vengeance (8.12). Mention of the funeral, in the church Clovis and Chlotild had built, of Chlotild's 7 and 10 year old grandsons, murdered by their uncles, emphasises the pathos of their ends and the hastiness of their grandmother in surrendering them, reflection upon which must have caused intensified her grief. Gregory's approving account of her prayers, vigils, almsgiving, humility and largess to religious foundations could be taken as owing something to remorse and guilt, though it is the conventional praise of pious queens (3.18).

Different circumstances in 584 and a different character shaped the response of Fredegund, convinced that her son Theuderic had been killed by witchcraft. She pursued her inquiries with multiple arrests, beatings and tortures. The chief suspect was cruelly tortured and then exiled, but expired on the outward journey. Her reaction to bereavement was not only ferocity but also memory-erasure: she filled four carts with her late son's precious possessions and burnt them. Apart from keeping the melted gold and silver therein, she acted "lest anything remain intact that might remind her of her mourning (planctum) for her son". (6.35). In 580, there had been an earlier illustration of Fredegund's penchant for manic defences against feeling helpless and broken. ${ }^{39}$ Then, too, she coped with bereavement by planning harm to others, admittedly after being thoroughly alarmed by the boasts of her stepson Chlodovech. She and Chilperic spent October mourning the loss of two sons while she intrigued to bring about the death of Chlodovech. Whatever consolation she received was insufficient balm. ${ }^{40}$ Besides achieving the end of Chlodovech, cruel deaths and tortures were inflicted at her bidding upon various people associated with him. ${ }^{41}$ She initially, and so in Gregory's eyes correctly, made sense of the eventually fatal illness that afflicted her younger son, Dagobert, by ascribing it to divine displeasure at her husband's unjust rule and, in fear of eternal damnation, persuaded him to display penance and revoke some planned taxes. Allegedly, as the plague of that year took its toll, she saw in the tears of the poor, the lamentations of widows and the sighs of orphans signs of divine anger at royal avariciousness. ${ }^{42}$ Royal penitential behaviour did not save the younger son nor, a little later, the elder, Chlodobert. After describing the funerals for the boys and public displays of grief, Gregory adds that Chilperic "made generous largess to cathedrals, churches and the poor". After the first bereavement Fredegund must have wondered about the efficacy of such piety, if her subsequent reactions to the deaths of Chlodobert and Theuderic are anything to go by. Anger and desire for vengeance are common companions to loss, especially if foul play is evident, suspected or eagerly believed, and the loss seems particularly unwarranted and follows a display of penance. Dolor, significantly, can mean resentment as well as grief. ${ }^{43}$

\footnotetext{
39 5.39. On her extravagant grief then, see Wood 1994: 124.

40 See George 1992: 85-92 on how Gregory's contemporary, Venantius Fortunatus, dealt with the theme of consolation and sought to console the king and queen.

${ }^{41}$ Violent reaction to a different kind of relationship loss, that of his wife to his nephew, is Duke Desiderius' killing of the nephew, 10.8 .

42 5.34. More on this kind of response below. Gregory describes the funerals for the boys and the public displays of grief. When their second child died shortly after, Chilperic gave generously to churches, cathedrals and the poor, no doubt out of a reinforced sense that he was being punished for his sins.

${ }^{43}$ Braund 1997.
} 
The savage but in some ways model Christian, Clovis, was susceptible to a gentler way of response to bereavement, although he was not threatened by it in the way Fredegund was. The saintly Bishop Remigius consoled Clovis with the observation that his late sister Albofled, having been baptized in the right faith, should be admired and celebrated as an inspiration rather than mourned (2.31). Bereavement therefore became a test of his faith. This was how the Catholic faith should be promoted: the hope of Christian salvation eased the pain of loss. Whenever someone full of piety and exemplary good works dies, as when Bishop Martin of Galicia left his flock and departed to the Lord, correct consolation stood ready to ease the pain (5.37). Gregory reports that the pain of losing young children in the plague that swept almost all Gaul in 580 was hard to bear because they were "so sweet and dear to us, whom we had cherished in our bosoms and carried in our arms, fed with our own hands, and nourished with all the care and knowledge that we had". But the correct consolatory response to such sorrow, which no doubt Gregory as bishop repeatedly resorted to, was to wipe away the tears and accept, like Job, what God disposed: "the Lord gave, the Lord hath taken away; as it hath pleased the Lord, so let it come to pass". ${ }^{44}$

\section{Response to loss of status or possession.}

Fredegund's response to a different kind of loss (category 2), her queenly power and status, was also vigorous. Virtually exiled after the death of Chilperic, she grieved (valde maesta) but typically turned her demonic energies into plotting against Queen Brunhild, widow of King Sigibert and a much-hated rival of Fredegund. Having sent against her an assassin who failed in his task, she relieved her feelings of disappointment by having his hands and feet amputated (7.20).

In one of the more detailed secondary responses to this cause of grief, Bishop Brice berates himself for his earlier abuse of his predecessor, St. Martin, which he saw as the cause of his current woes, namely, the loss of his bishopric following a charge of impregnating his washer-woman. He went to Rome to tearfully (flens et eiulans) confess to the Pope that he had erred in deriding Martin. Brice here illustrates a common motive for a display of grief, to gain mercy and to stir anger against the injustice of others in seeking to have a source of grief removed. This and much subsequent tearful remorse seem to have prevailed over what Gregory, apparently influenced by Brice's display, calls the persistent "evil ways" of the population of Tours (in sua malitia perdurantes) and Brice was restored to the bishopric (2.1). An edifying tale of grief at prospective loss, in this case of virginity and a place in Paradise, is that of the bride of Injuriosus on her wedding night. Weeping copiously, she engages in a

\footnotetext{
44 5.34, Job 1.21. The plague in 590 that left so many mourners at Rome was not an unmitigated evil, Gregory thinks, if, besides sighs and lamentation, it induced repentance, 10.1. There was little resigned or restrained about the responses in the harrowing scenes of grief that Gregory depicts when royal serfs and other free men of good birth were conscripted to accompany Fredegund's and Chilperic's daughter Rigunth on her journey to Spain to marry the king's son in 584. Unlikely to ever see their dear ones again, this was like a permanent exile, even a living death. In fact, some made wills that were to be opened when Rigunth reached Spain "as if they were already in their graves", 6.45. Chilperic tried to discourage resistance by imprisoning the weeping reluctant. But "many facing a bitter fate hanged themselves, in dread of being carried off from their nearest and dearest...they departed with groans and curses. There was so much lamentation in Paris that it was like the lamentations of the Egyptians."
} 
long (and imaginary) discussion of what is at stake that results in an excellent outcome for both bride and groom: they both dedicate themselves to and achieve a sexless marriage and union in heaven. ${ }^{45}$ Gregory uses this emotional moment to again make the case for the glory of virginity. A display of grief has proven salutary. If tears are natural, initial and primary responses to the loss of possessions or status, correct secondary responses include confession, or prayer that, if possible, the loss be reversed. This was done in the case of a stolen possession, a precious relic. The merchant Eufronius wept when Duke Mummolus stole his relic but he prostrated himself and prayed for its return. The fusion of primary and secondary response that is lachrymose prayer or supplication demonstrated its effectiveness, for Eufronius regained most of the relic (7.31). Tears continued and co-existed with the secondary response and reinforced it.

\section{Grief, petition to and compassion for mortals.}

As they are in many cultures, whether Christian or non-Christian, tears, prayer and prostration are also in Gregory's world the proper way to supplicate mortals and to prevent a prospect that both alarms and grieves. In her letter to the bishops concerning the revolt of some of the nuns at Poitiers, the saintly ex-queen Radegund, who had founded the convent, wrote: "And since I am unable to cast myself at your feet in person, I am prostrating myself through this letter...I beg with many tears that this my petition...be kept among the archives" (9.42). Cultural custom rather than holy tears best describe and account for the manner of Fredegund's supplication on one occasion. When her detested enemy, Leudast, prostrated himself before her in a church, begging forgiveness, she responded by rejecting him and, in tears, threw herself at Chilperic's feet, saying: "Woe is me that I see my enemy in person and am powerless to do anything against him". ${ }^{46}$

Grief, mainly episcopal, felt on behalf of what others suffer or may suffer, is a category comprised of material considered worthy of inclusion in the historical record because it provides edifying stories of Christian petition, protection, prayer, prostration, charity and compassion, or, in some cases, frustrating inability to help. ${ }^{47}$ Such stories help neutralise the sentiment, common in Gregory, that people who suffered loss are guilty, sinful and are being punished by God.48 A good early example of such compassion is Bishop Desiderius grieving (dolebat) for the poor and destitute of Verdun. His pious plea on their behalf to King Theuderic's piety was so successful

\footnotetext{
45 1.47: contristata...amarisssime flebat...plangam...tantae lacrimae...dolorem...cum magno fletu. On this story, see Rosenwein 2002b: 843.

${ }^{46} 6.32$. Fredegund's distress is perfectly credible, but on the proven efficacy of tearful feminine entreaty, see Lutz 1999: 56-60. Leudast was expelled and soon killed. Cf. the tearful and unsuccessful supplication of Childebert I's and Chlothar's nephew, 3.18.

47 Bishop Ageric of Treves tried to protect the fugitive Berthefred who took sanctuary in his church, trying to escape the wrath of Childebert, and was very distressed when Childebert's agents broke in and killed Berthefred and three of his servants, not least because a holy place had been sacrilegiously defiled with blood, 9.12. Gifts sent by Childebert to comfort Ageric in his grief failed to do so. Ageric's feelings of impotence and failure were compounded by the subsequent killing of another magnate whose protection he had guaranteed, Guntram Boso, 9.23. Cf. 9.10: and he daily lamented (cotidie flerit) the lot of Boso's sons, who lived with him. Ageric's sense of guilt and failure supposedly helped to drive him to an early grave.

${ }^{48}$ Cf. Van Praag 1988.
} 
that the king gave him 7000 gold pieces to distribute and greatly enrich the inhabitants (pietas...pietate commotus, 3.34). Bishop Egidius' fellow bishops sighed (suspirantes) and grieved (lamentantes) at his admission of guilt on several serious charges when on trial before King Childebert, and urged him to find a way of clearing himself. They failed but they interceded successfully for his life. ${ }^{49}$ In part, their concern was driven by the disgrace (obpropium) this turbulent cleric had brought to the bishopric. Perhaps a more an exemplary act of collegial compassion occurred when, Pientius, Bishop of Aix, provided much needed assistance to Bishop Theodore as the latter, attacked and persecuted in various ways by the governor of Provence, passed nearby on his way to face trial by Guntram: "feeling sorrow for his brother's lot (condolens fratri), he sent clerics to help him and provided him with what he needed" (6.11). Later, it was the sorrowing (tristis) Ageric's turn to visit Theodore in captivity, kissing him and giving him clothing. There are elements of bishops closing ranks in the face of secular assertiveness in these stories about Egidius and Theodore but Gregory presents them worthy examples of sorrow-driven, and in Theodore's case, properly performed, compassion.

\section{Grief and petition to the divine.}

Ageric did more than comfort Theodore in captivity. He wept, prostrated himself and prayed for help for his brother bishop. It was also a mark of Bishop Magneric's holiness that he wept, prayed and prostrated himself before the tomb of St. Maximinus on behalf of Theodore, who was soon restored to his see..$^{50}$ The capacity of tears, groans and humble posture to invoke the sacred and divine when accompanied by prayer is further illustrated by Bishop Mamertus of Vienne, when a series of portents, including a fire in the palace, terrified his congregation. Prostrate before the altar, he begged God's mercy. Gregory continues: "What more is there to say? The prayer of the famous bishop penetrated to the heights of heaven; the river of his flowing tears put out fire in the palace" (2.34). This initiated a sequence of piety and virtue in the congregation. Prayer, fasting, almsgiving brought the other terrors to a halt. Mamertus' compassion inspired other bishops to make such practices part of the litany and so blend grief, remorse, contrition and good works. The prayers of Bishop Aravatius of Tongres that the Huns not invade Gaul in 451 may have played some part in all this (the Huns did enter Gaul, but, defeated by Aetius, did not remain). He besought God's mercy with fasting and vigils, "soaked in a flood of tears" (2.5). Or so Gregory imagines it, for this was the correct procedure. At the same time, Bishop Anianus of Orleans urged tears, lamentations and prostration upon his flock as they prayed for the deliverance of their city from the Huns. They did so, and were spared (2.6). The pattern is one of grief and fear for one's safety, tears for one's sins, and joyful relief at deliverance, but it is the tears of the intercessor in these stories that Gregory emphasises. Nor was such effective intercession confined to bishops. ${ }^{51}$ In another

\footnotetext{
${ }^{49}$ Then they dismissed him from his position, 10.19. For similar distress by bishops at the conduct of a bishop, in this case Praetextatus, see 5.18.

${ }^{50}$ 8.12. Cf. 6.6, 6.36, 10.8 .

${ }^{51}$ It was the key to the successful appeal to God of the hermit Eparchius, grieving for an accused criminal about to be hanged was similarly conducted and led to the man's miraculous release from bondage,6.8. On the Aravitius and Eparchius episodes, see DeNie 1987: 32, 266, and cf. 284. Less dramatic, more egocentric but also successful was the tearful prayer for relief of one of the Count of
} 
impressive petition for another's safety, the unceasing tears and prayers of the wife of Roman generalissimo and Hun-resister, Aetius. She was able to secure his safe return from Gaul even when, allegedly, divine judgement had originally decreed otherwise. Angels, however, interceded with God to revoke this decree. Tearful appeals can also be made directly to persons in danger of losing their souls. In Spain, in a letter to his flock to remain in the Catholic faith and not embrace Arianism, Bishop Eugenius is at least to some extent appealing to the power of lachrymose prayer when he says that he beseeches them with tears. He fears they will have much to dread on Judgment Day if they succumb (2.3).

Gregory was heir to a scriptural and ascetic tradition that privileged certain types and displays of grief and which he could plausibly depict as pious behaviour. Besides, tears can be shed for joy, relief or when one is moved by some gesture, kindness, beauty, august presence or by the urgency of the need for help or mercy. Tears signify not only grief but also an activity, that is commonly accompanied by prayer and prostration and which has a cathartic, cleansing, releasing effect (as do the tears of bereavement, loss, disappointment, failure, frustration, impotence, rage). When tearful supplication is directed at God or the saints, feelings of grief can segue almost imperceptibly into tears of relief and joy, particularly if being abundantly lachrymose was regarded as a divine gift. Part of that joy comes from the sense of imitating and therefore drawing closer to Jesus, the angels, even God, and the comfort and compassion they offer. As Jesus put it, "Blessed are they that mourn: for they shall be comforted" (Matthew 5.4). These tears are a gift. Jesus set an example of such virtuous emotion. He wept, prayed and supplicated, and God heard him. ${ }^{52}$ Much prayer in Gregory's world is, in fact, a form of anguished grieving, a heart grief, whether for one's own sins or for the sins and (therefore) sorrows of specific others or of humanity in general. ${ }^{33}$ Gregory clearly embraces these Biblical injunctions that make it appear sinful not to humbly mourn and groan for the human condition and the legions of the lost. Tears, hairshirts, prayers, petition and prostration are both commonplace signs of and responses to this particular form of grief. The pious, repentant, humble and saintly will therefore be frequently depicted by Gregory as engaged in a form of painful healing, an activity that suggests masochism and but its payoffs for him is more about seeking to rise to the heights of divine compassion. ${ }^{54}$

Bourges' servants after trespassing in a house belonging to St. Martin, 7.42. Prayer, tears and prostration enabled St. Walfroy to have a large statue of Diana pulled down when the efforts of some pious locals had hitherto been unsuccessful, 8.15.

${ }^{52}$ Hebrews 5.7-8. For Old Testament antecedents, see Psalms 56.8, Exodus 22.29. If God keeps our tears in a bottle and writes each one in his book, if God considers them an offering and a treasure in heaven, then both the merit of the activity and its releasing effect lift the heart. For penitential practises in the early Church and ascetic tradition, and their connection with miracles, see Rapp 2005: 77-81. As Rosenwein 2006: 178, puts it, “The joyful heart and the tearful prayer are two sides of the same coin". Cf. Lutz 1999: 214-16.

53 See Psalms 126. 5-6, Ecclesiastes 3.4 and cf. James 4-6-10.

${ }^{54}$ For the virtues of humility and self-humiliation, see Geary 1994, and DeNie 1987: 134-35, 203, 284. Such behaviour was a striking contrast to the arrogance of many magnates and bishops. The argument for masochism would run along the lines that self-abasing behaviour seeks to seduce the humiliator, to control the punishment and sadism of the more powerful. A key to this process lies in the single etymological root of pain, punish and penalty, namely Latin poena. But note that such activity can be seen as a way of engaging with and defeating evil, and so would help to combat feelings of helplessness and depression. See Stancliffe 1983: 229-35. 
To the extent that the sublime is glimpsed or sensed, a primordial sense of separation, of guilt and unworthiness, of exile from paradise, of yearning to return home, these will all induce sorrow as well as joy. ${ }^{55}$

\section{Penitential grief and response.}

Prominent in Gregory is grief as a form of awareness that presses upon sinners (category 4) and which induces penitential responses. True repentance might save one from further suffering in this life and the torment that awaited sinners in Hell. ${ }^{66}$ Successful repentance is illustrated early by the Jews who not only groaned (ingemiscunt) for their neglect of the commandments after the death of Joshua but by their repentance (conversi) secured their freedom. ${ }^{57}$ Successful too was the repentance of Bishop Urbicus who, married at the time of his assumption of office, eventually succumbed to his wife's persistent demands for sex and deeply regretted the lapse. He dismissed her permanently, "and to do penance for his misdeed, made for a monastery; (and) there (he) washed away his offence with groans and tears" (1.44). Possibly successful was the repentance of King Leuvigild of Spain, who in 587 fell ill, repented of his Arian heresy, embraced Catholicism, banned the heresy in his kingdom, and "was continually in tears for seven days on account of all the evil which he had done against God, after which he gave up the ghost": laudable measures to be sure, but Gregory reserves judgment on the genuineness of it all with the introductory comment, "some say" (ut quidam adserunt, 8.46). Unsuccessful repentance, however, seems to have been the lot of King Chlothar who went to St. Martin's tomb, confessed all his evil deeds and "with many a groan (cum grande gemitu) prayed the blessed confessor to implore the Lord's mercy on his offences, and by his intercession wash away the sins he had thoughtlessly committed". He died within a year, very much a tormented soul, on the anniversary of his killing of his son, Chramn, surely (for Gregory) no coincidence (4.21). Likewise futile in Gregory's view was the repentance of King Sigismund, who repaired to a monastery in guilty anguish after allowing his son to be strangled after he had reproached and enraged his stepmother, dressed in his late mother's clothes. He wept and fasted for many days, begged for God's pardon and founded perpetual chants. But his repentance, however genuine and deep, and his good works were in vain, for "divine vengeance followed in his footsteps". 58

\footnotetext{
${ }^{55}$ Cf. Gregory's report of the vision of Salvius in a near-death experience that granted him access to the splendour of heaven but which induced immense sorrow when he was told to return to earth, 7.1 Also, Patton and Hawley 2005; Lutz 1999: 33-36.

${ }^{56}$ Gregory assures us that those Spaniards who in the Fifth Century deserted the true faith and embraced heresy for the sake of riches knew only suffering, inseruerunt se doloribus multis, 2.3. Abbott Suniulf's vision of hell had sinners crying and weeping as they burnt: clamantes cum fletu, 4.33.

57 1.12. This is all very relevant as Gregory sees the people of his own time as being in a direct Biblical succession to the Jews. See Wallace-Hadrill 1968: 37.

58 3.5. There is a sense of dutiful piety about Gregory's responses to distaste for the task of chronicling the crimes and suffering of his times, at 4.50 twice, 5.18, and 10.15 (category 5). But there were good deeds to be recorded too and in his preface to the work as a whole Gregory refers to a general lament, ingemescebant, that a record was not being kept. Obviously sharing some of this sorrow, Gregory dutifully if diffidently responded to it, starting upon the task and persevering. To be sure, such expressions of distaste are a historiographic convention, but they also suggest the toll his task exacted upon him. "To relate these civil wars fills my heart with grief, ingerit dolorem", 4.50, as do events such as the despoilment of Theudebert's corpse, dolor dici, ibid. Gregory's heart is heavy at having to recount the sycophantic behaviour of some fellow bishops, quod de episcopis dici dolendum est, 5.18. Who, he asks,
} 


\section{Power and affiliation drives}

The power drive, the drive or motive to control and influence others, to show dominance and control one's own fate has been extensively studied by scholars. Gregory's History naturally contains much such behaviour as he chronicles the aggressive deeds of kings, queens, magnates, some clergy and some commoners. Much of the abundant violent physical behaviour he records is fuelled by the drive for power, as are words designed to influence and persuade. However, one of this drive's elements is fear of being or seeming weak or wounded, an element that is usually concealed by the aggressive, dominant behaviour. Occasionally this fear is manifest, as when Gregory reports Fredegund behaving counter-phobically, having been threatened by her stepson after the death of her own sons in 580. Mostly, however, it is latent in the narrative, although in many episodes of anger and the violent action it leads to, the desire to conceal a wound and a vulnerability is discernible. ${ }^{59}$

The affiliation drive is the concern over establishing, maintaining or restoring positive relations with another person, persons or group, the desire to be liked, accepted, forgiven. It is essentially irenic. If a relationship, notably with the divine, has been disrupted, steps are taken to repair it. One of this drive's elements is the fear of being rejected or abandoned. It is easy to see a great deal of placatory and penitential behaviour in Gregory as driven by this fear. Implicit in his message is that forgiveness, especially on Judgement Day, is good and any vengeance is best left to God or the saints. Humble, submissive behaviour therefore is not just about selfpreservation, it is the affiliative drive to avoid or remove interpersonal conflict.

\section{Conclusion}

What is interesting and useful about Gregory's portrayal of fear and grief? When emotional behaviour is portrayed by a historian like Gregory, we get a religioninfused snapshot of the never-ending process whereby emotions, more specifically the assessment of those emotions, both cause and reflect social change. There is an interaction between an author, his or her agenda, and events described which reveals the values and assumptions of the historian and, less certainly, of the actors in the drama, who may be emoting and performing in certain, often calculating and theatrical, ways. They might seek to manipulate and influence others as a form of politics or means of self-preservation. When people observe, read or hear of emotions present in others, they may share or reject, approve or disapprove of those emotions and re-

could refrain from tears when relating the sorry events, a revolt by nuns, at the Poitiers monastery, quis...tanta mala verbis poterit explicare... sine fletu?, 10.15. On Gregory's grief about this, see Rosenwein 2006: 124. He would have felt the same distaste for relating the sorry behaviour of some of his fellow bishops. See Begbie 1969: 263. There is enough in the above responses to show that grief can be an amalgam of sadness, fear, anger, helplessness, guilt and despair. Petition, prayer, piety and penance are evident in over 70 of our 96 instances, whether undertaken on behalf of the self, others or both.

59 See Smith 1992: 205-224, 278-300. On the counter-phobic, wound-concealing nature of much anger in Gregory, see Newbold, forthcoming. 
sponses to them, whether recent or distant. Plato and the Stoics had deplored emotions as irrational passions, regrettable losses of self-control, best avoided altogether in favour of impassivity, although a few "good" secondary responses to stimuli were privileged. Even Aristotle's more cognitive approach to emotions classed most of them as sorrowful and painful. The gravitas or reserved dignity of Romans of old also provided a model of endurance and decorum for Christians. ${ }^{60}$ However, an at times agonistic but typically affiliative drive to demonstrate the extent of one's Christian faith and devotion fostered extravagant and consciously passionate displays of penance and grief for one's sinfulness and unworthiness, exhibitions of how much one loved God and pitied the sufferings of others. The historian may suspect rather than know for certain exactly what takes place on a certain occasion but, by drawing upon the commonplaces of expected behaviour, may claim to know in order to make some point, such as the virtue of making visible one's fear of God or one's grief at sinfulness and separation from God. ${ }^{61}$ We see in Gregory that, besides sadness and despair, grief can encompass fear, anger, guilt, helplessness, and stimulate action that is salutary for the self and for others. Or if not salutary for the self, at least offer some respite from anguish. It arouses, or seeks to arouse, pity and compassion, and it may seek some form of retribution. Grief, especially bereavement grief, typically leads to attacks of yearning, hunger for beauty and physical touch, anxiety, depression, despair and idealisation of the departed. One can see signs of some of these in Gregory's historical material but he has a particular interest in grief at sins, sinfulness and unworthiness, as well as showing, in a poor light, the anger that may also be the consequence of both fear and grief. ${ }^{62}$ While the statement, "Neither Protestant nor Catholic Christianity encouraged grief", ${ }^{63}$ might apply to bereavement grief, it does not in Gregory apply to displays of this or other forms of grief. In this he was distinct from that stream in the ascetic tradition and which surfaces in Gregory's contemporary, Pope Gregory, that distrusted emotion, even sin-driven penance, because such sorrow was at odds with the ideal of impassivity. ${ }^{64}$

Severe grief is always transformative and it is the guilt-ridden, griefstimulated change towards greater piety that most engages Gregory. Fear may have a greater role in some of the tearful supplications he narrates if there are masochistic elements present, elements that are really about controlling anxiety and fears of rejection by in turn controlling the manner and extent of punishment and rejection the miserable, guilt-ridden sinner is liable to. ${ }^{65}$ What is surprising, given the propensity of so many of Gregory's characters to display anger and resort to violence, is the rarity of the angry, counterphobic response to fear, because anger inhibits fear. However, Gregory tends to see anger, unless divine and therefore justified, as a regretta-

\footnotetext{
${ }^{60}$ See Nussbaum 1994: 60.

${ }^{61}$ On Gregory's agenda and his didactic presentation of events, see Heinzelmann 2001: 36, and WallaceHadrill 1968: 44: "the descriptions of kings we meet in Gregory and Bede, though based on authentic information... are literary creations, one effect of which would be to make readers and hearers consider the problems of kingship as they met it in the light of the past".

${ }^{62}$ Cf. Rosenwein 2002a: 32: “Written down, they (emotions) might just possibly effect a conversion - in the reader." Missing from our sample, for instance, are clear cases of taking on a cause or belief dear to the lost beloved as a way of honouring their memory.

63 Stearns and Knapp 1996: 133.

${ }^{64}$ See Rosenwein 2006: 83.

${ }^{65}$ Messaker 1957; Bieber 1953.
} 
ble, often shameless, loss of control and he favours more irenic, submissive and placatory, and therefore, as he sees it, more Christian, responses. ${ }^{66}$ These responses, resembling a good deal of what piety entails, are, after all, very successful. As people prostrate themselves before God and beseech with tears his forgiveness, mercy and aid, their hearts can be read by divine insight. Humans, particularly when they are fearful, and acknowledge and seek to alleviate it by placatory and conciliatory behaviour may also be setting a trap for the momentarily dominant party. Or they may be lulled into thinking they have been completely and permanently forgiven when apparent forgiveness only masks plans for retribution. Grief too can be feigned. But Gregory, while on the one hand depicting a society riddled with insincerity, deceit and treachery, ${ }^{67}$ nevertheless prefers to focus on marks of humility, penance, peacefulness and piety. Responses to fear are presented mainly as sensible acts of selfpreservation rather than disgraceful cowardice, especially if it is induced by wicked and outrageous behaviour that shows no fear of God. When the strong humiliate the weak, it is the former who should fear the future most. If fear informs one's attitude to God and the saints, it must be good for individual and society, in Gregory's view. Grief offers opportunities to do good work and re-engage with God and the life of the spirit, to repair a relationship. Most responses to grief feature at least one of petition, prayer, prostration and penance, and these acts can overcome helplessness, abandonment, guilt, despair and fear of the future. The fearsome divine punishment that inflicts loss and grief upon sinners also stands ready to bring to justice the human inflictors of the same.

Dr. Ron F. Newbold

University of Adelaide

E-mail:ron.newbold@adelaide.edu.au

${ }^{66}$ Reynolds 1980.

${ }^{67}$ See Brown 2002: 17-19. 


\section{Bibliography}

Averill, J. (1994) 'Emotions are many-splendoured things.' - Ekman, P.; Davidson, R. (edd.), The nature of emotion. Oxford: Oxford University Press, 99-102.

Begbie, C. (1969) A study of Gregory of Tours and his times. Dissertation: University of London.

Bieber, I. (1953) 'The meaning of masochism.' - American Journal of Psychotherapy 7, 433-448.

Braund, S. (1997) 'A passion unconsoled? Grief and anger in Juvenal Satire 13.' Braund, S.; Gill, C. (edd.), The passions in Roman thought and literature. Cambridge: Cambridge University Press, 68-88.

Brown, P. (2002) 'Gregory of Tours: Introduction.' - Mitchell. K.; Wood. I. (edd.), The world of Gregory of Tours. Leiden etc.: Brill, 1-28.

Chodorow, J. (1991) Dance therapy and depth psychology. London: Routledge.

Dalton, O. (1927) The history of the Franks. 2 vols. Oxford: Clarendon Press.

Davies, W. (1987) 'The varieties of fear.' - Philosophical Studies 51, 287-310.

DeNie, G. (1987) Views from a many-windowed tower. Studies of imagination in the works of Gregory of Tours. Amsterdam: Rodopi.

Frye, D. (2003) 'From locus publicus to locus sanctus: Justice and Sacred Space in Merovingian Gaul.' - Nottingham Medieval Studies 47, 1-20.

Geary, P. J. (1994) 'The humiliation of saints.' - Geary, P. J., Living with the dead in the Middle Ages. Ithaca: Cornell University Press, 95-115.

George, J. (1992) Venantius Fortunatus. A Latin poet in Merovingian Gaul. Oxford: Clarendon Press.

Goldsworthy, K. (2005) 'Grief and loss theory: all changes involve loss, just as all losses require change.' - Australian Social Work 58, 167-178.

Harre, R. (1986) Social construction of the emotions. Oxford: Blackwell.

Heinzelmann, M. (2001) Gregory of Tours. History and society in the Sixth Century. Trans. Carroll, C. New York: Cambridge University Press.

James, E. (1982) The origins of France. London: MacMillan.

Klass, D. et al. (edd.) (1996) Continuing bonds. Washington: Taylor and Francis.

Konstan, D. (2006) The emotions of the ancient Greeks. Studies in Aristotle and ancient literature. Toronto: University Press.

Krippendorf, K. (2004) Content Analysis. 2nd ed. London: Sage.

Kristeva, J. (1989) Black sun: depression and melancholia. Trans. Roudiez, L. New York Columbia University Press.

Kruger, P. (2004) 'On emotions and the expression of emotions in the Old Testament: a few introductory remarks.' - Biblische Zeitschrift 48, 213-225.

Lutz, T. (1999) Crying. The natural and cultural history of tears. New York: Norton.

Messaker, E. (1957) 'Masochism - a defensive reaction of the ego.' - Psychoanalytic Quarterly 22, 200-220.

Milton, K; Svasch, M. (edd.), (2005) Mixed emotions: anthropological studies of feeling. Oxford: Berg.

Newbold, R. (1994) 'Interpersonal violence in Gregory of Tours' Libri Historiarum.' Nottingham Medieval Studies 38, 3-17. 
Newbold, R. (forthcoming) 'The nature of anger in Gregory of Tours' Libri Historiarum.' - Nottingham Medieval Studies.

Nussbaum, M. (1994) The therapy of desire. Princeton: Princeton University Press.

Patton, K.; Hawley, J. (edd.), (2005) Holy tears. Weeping in the religious imagination. Princeton: Princeton University Press.

Rapp, C. (2005) Holy bishops in late antiquity. Berkerly: University of California Press.

Reynolds, B. (1980) The beatific and the bestial: Gregory of Tours' perspectives on war. Dissertation: University of Kentucky.

Rosenblatt, P. et al. (edd.), (1976) Grief and mourning in cross-cultural perspective. New Haven: Yale University Press.

Rosenwein, B. (2002a) 'Writing and emotions in Gregory of Tours.' - Pohl, W.; Herold, P. (edd.), Vom Nutzen des Schreibens. Vienna: Österreichische Akadamie der Wissenschaften, 23-32.

Rosenwein, B. (2002b) 'Worrying about emotions in history.' - American Historical Review 107, 821-845.

Rosenwein, B. (2006) Emotional communities in the early Middle Ages. Ithaca: Cornell University Press.

Smith, C. (ed.) (1992) Motivation and Personality. Handbook of thematic content analysis. Cambridge: Cambridge University Press.

Smith, J. (2005) Europe after Rome. A new cultural history 500-1000. Oxford: Oxford University Press.

Stancliffe, C. (1983) St. Martin and his hagiographer. Oxford: Clarendon Press.

Stearns, P.; Knapp, M. (1996) 'Historical perspectives on grief.' - Harré, R.; Parrott, W. (edd.), The emotions. Social, cultural and biological dimensions. London: Sage, 132-150.

St-Michel, D. (1979) Concordance de l'Historia Francorum de Gregoire de Tours. Montreal: Université de Montreal.

Van Praag, H. (1988) 'Job's agony: a biblical evocation of bereavement and grief.' Judaism 37, 173-187.

Wallace-Hadrill, J. (1968) 'Gregory of Tours and Bede: their views on the personal qualities of kings.' - Frühmitteralterliche Studien, 2, 31-44.

Wood, I. (1994) The Merovingian kingdoms 450-751. London: Longman. 